Arab Univ. J. Agric. Sci., Ain Shams Univ., Cairo, 14(1), 289-297, 2006

\title{
PREPARING NEW BLENDS OF FRUIT JUICES TO MEET THE NEEDS OF THE POTENT ANTIOXIDANT EFFECTS
}

[19]

\author{
Nagwa, F. El-Sharouny ${ }^{1}$
}

\begin{abstract}
New fruit juice blends which contain several potent antioxidants (carotenoides, ascorbic acid and selenium) in combination with other favorable aspects of flavor and color were tried. The trial included locally produced fruits such as Kaki, Papaya, Guava and Pomegranate. Five blends were prepared with different percentages of the prepared juices in trying to maximize the required nutrients such as carotenoides, ascorbic acid and other micro-nutrients. The best blend which had the highest content of ascorbic acid $45.73 \mathrm{mg} / 100 \mathrm{gm}$ was blend No.(2) which contained $30 \%$ kaki, $30 \%$ papaya, $30 \%$ guava and $10 \%$ pomegranate whereas blend No.(4) (50\% kaki, $30 \%$ papaya, $10 \%$ guava, and $10 \%$ pomegranate had the highest content of carotenoids $(33.58 \mathrm{mg} / 100 \mathrm{gm})$. Selenium content of different blends were almost always the same. Organoleptic scores revealed that the best consumer preference was for blends No. (2 and 4). As for main components of different blends a slight difference could be observed between percentages of sugars and titratable acidity.
\end{abstract}

Keywords: Blend fruit juices, Antioxidant effects

\section{INTRODUCTION}

New fruit juice blends which contain several potent antioxidants in combination with other favorable aspects of flavor and color were tried.

Nowadays the consumption of juices of high nutrient value is recommended to satisfy the needs of vitamins, minerals and organic acids. In this respect, many investigators prepared several juice blends to maximize the required micronutrients.
Locally produced fruits such as Kaki, Papaya, Guava and Pomegranate could be used to prepare such blends of high nutritious value.

In this respect, Kaki or Persimmon (Diospyros kaki), Papaya (Carica papaya L.), Guava (psidium guajava L.) and pomegranate (Punica granatum) were used.

Kaki fruits differ from orange to red in color, firm to soft in texture, astringent to non-astringent in taste, and seedy to seedless according to cultivars (Philip and Chen 1988).

1- Food Tech. Res. Institute, Agric. Res. Center, Giza, Egypt

(Received November 12, 2005)

(Accepted December 10, 2005) 
Generally, the pulp of this fruit has $76.3-79.7 \%$ moisture, $16.4-20.7 \%$ total soluble solids, $11.4-16.2 \%$ total sugars, $0.76-1.09 \%$ crude fiber, $0.49-0.80 \%$ protein, $0.08-0.23 \%$ lipids, $0.48-0.80 \%$ ash, $0.14-0.30 \%$ total acidity as citric acid and 6.01-6.03 pH value (Homnava et al 1990 and Aksu et al 1994). However, It is considered a poor source of ascorbic acid $(18.28 \mathrm{mg} / 100 \mathrm{~g})$ while it is rich in carotenoides $(43 \mathrm{mg} / 100 \mathrm{~g}$ as $\boldsymbol{\beta}$. carotene) (Lee and Kin 1994). In Egypt, the cultivation and production of this fruit are recently introduced.

On the other hand, Papaya (Carica papaya L.) is melon like and when becomes fully ripe its flesh is slightly aromatic with yellow to orange color. (Pal et al 1980) studied the chemical composition of twelve Papaya fruit varieties and stated that they contained from 2.03 to $3.37 \%$ sucrose, 2.77-5.98\% glucose, $2.86-3.57 \%$ fructose, $46.3-125.9 \mathrm{mg} / 100 \mathrm{~g}$ ascorbic acid and $0.058-0.116 \%$ total acidity as citric acid on fresh weight basis (FWB).

The Papaya plantation is growing up quickly in Egypt. People demand it for stomach problems, in addition to its high protiolytic activity due to the presence of Papin enzyme (Subramanyam et al 1986).

Recently, (Chandrika et al 2003) mentioned that Papaya is one of the main fruits recommended for vitamin A deficiency in Sri-Lanka. The carotenoids are known to be involved in immune enhancement, treatment and prevention of cancer and of antioxidant capacity (Bendich 1991 and Mathews-Roth 1991).

Beside, Guava (Psidium guajava L.) is a tropical fruit grown in several areas and in Egypt.
However, it is grown successfully and considered as excellent fruit for its highest ascorbic acid content, and some other nutrients as well as the pronounced delicate flavour.

Chemical composition of fresh guava fruits has been studied by Scudamore (1987), who reported that guava juice had $\mathrm{pH}$ value ranging from 3.1 to 3.8 , titratable acidity $0.6-1.8 \mathrm{mg} / 100 \mathrm{ml}$ as citric acid and $66-171 \mathrm{mg} / 100 \mathrm{~g}$ ascorbic acid.

The pomegranate (Punica granatum) is a tropical and or subtropical tree. (Tressler and Joslyn 1971) mentioned that pomegranate had reducing sugars $16.9 \%$ and organic acid $1.6 \%$ as citric acid.

(Shrede et al 1992), found that anthocyanins are the main natural pigments of pomegranate juice and these pigments could easily be oxidized or reduced by heat, metals and enzymes.

Accordingly, several blends were prepared from the different fruits juices in order to reach a high level of total antioxidant activity such as (carotenoids, vitamin $\mathrm{C}$ and selenium as well as valuable nutrient elements as $\mathrm{Ca}, \mathrm{Zn}$ and $\mathrm{Fe}$ in combination with good color, flavor and aroma.

\section{MATERIAL AND METHODS}

Kaki fruits (Diospyros kaki), Guava (Spidium guajava L.), Pomegranate (Punica granatum) were obtained from local market, whereas, papaya fruits (Carica papaya L.) variety cylon red, were brought from an orchard in ElKassasine.

All the fruit samples were purchased at their top seasons in 2003 and 2004 respectively at their optimum maturities. 
Fruits pulp were extracted from the above mentioned fruits and homogenized through the use of high rotating blender, the pulps were strained through the muslin cloth to separate the seeds.
The obtained pulps were blended at different proportions according to the following Table (1).

\begin{tabular}{|lccccc|}
\hline \multirow{2}{*}{ Fruits } & \multicolumn{5}{c}{ \% of different juices incorporated in the blends } \\
\cline { 2 - 6 } & $\mathbf{1}$ & $\mathbf{2}$ & $\mathbf{3}$ & $\mathbf{4}$ & $\mathbf{5}$ \\
\hline Kaki & 25 & 30 & 40 & 50 & 30 \\
Papaya & 25 & 30 & 20 & 30 & 40 \\
Guava & 25 & 30 & 20 & 10 & 10 \\
Pomegranate & 25 & 10 & 20 & 10 & 20 \\
\hline
\end{tabular}

Thereafter, juices were bottled in $200 \mathrm{ml}$ - glass containers and pasteurized in water bath at $90^{\circ} \mathrm{c}$ for one minute, then the filled bottles were sealed with crown caps and followed by sudden cooling to room temperature before placed in the refrigerator at $7^{\circ} \mathrm{C} \pm 2^{\circ} \mathrm{C}$. The juice blends were sensory evaluated by well trained panelists, who gave scores for the color, flavor and over all acceptability as described by Larmond, (1970).

The data obtained were statistically analyzed for the Least Significant Differences (L.S.D.) as described by Ott, (1984).

Fresh as well as processed juice blends were analyzed for moisture content, total soluble solids, total acidity (as citric acid), total sugars (reducing and non-reducing) ash, proteins, proteins and ascorbic acid (V.C) according to the methods described by AOAC, (1990). Pectin and $\beta$-carotene were determined as described by Ranganna, (1979). Whereas minerals $\mathrm{Ca}, \mathrm{Fe}, \mathrm{Zn}$ and Selenium were analyzed using the spectrophotometer - Perkin Elmer - 3300 after (Chapman and Pratt, 1961).

\section{RESULTS AND DISCUSSION}

Guava Fruit has a distinct strong flavor and white color, while persimmon (kaki) and papaya fruits have a weak flavor and orange to red color. Beside pomegranate has characterized flavor and naturally brilliant red color in acid media due to anthocyanins pigments (Hamed, 1999). Results in Table (2) indicate that moisture content of kaki pulp was $78.7 \%$ on (FWB). This result is in agreement with Aksu et al (1994). This value was less than that of papaya, guava and pomegranate which were $87.32,86.23$ and 85.87 respectively. A reverse trend was found for total sugars which was $17.11 \%$ and lower than that for both papaya and pomegranate except for guava fruit which had sugars level of $26.7 \%$ on FWB. 
Both reducing and non-reducing sugars were $16.85,0.26 ; 3.77,5.13 ; 12.20$, 14.50 and $6.20,3.31$ on FWB for kaki, papaya, guava and pomegranate, respectively.

According to (Tsuji and Komiyama 1987), sucrose was completely hydrolyzed after 10 minutes of kaki pulp homogenization. (Hirai and Yamazaki 1983) found that total sugars of Kaki fruit consisted of $39 \%$ fructose, $38 \%$ glucose, $23 \%$ sucrose. It differed from $11.5-19 \%$ according to kaki cultivars (Barbary, 1991; Manaba, 1993 and Aksu et al 1994).

Titratable acidity in kaki fruits and in papaya fruits were almost the same since they were 0.1 and $0.12 \%$ (as citric acid) respectively, whereas pomegranate had higher value $(0.69 \%)$ than guava $(0.42 \%)$. Results in the same table show that kaki and pomegranate were poor in ascorbic acid which was 14.79 and $12.40 \mathrm{mg} / 100 \mathrm{~g}$ respectively on (FWB). Guava and papaya fruits had a high level of ascorbic acid which was 64.58 and $69.50 \mathrm{mg} / 100 \mathrm{~g}$ (on FWB) respectively.

Both guava and papaya fruits could be considered as a very good source of vitamin $\mathrm{C}$ comparing with orange juice. The above mentioned results are in agreement with those reported by (Handwerk and Coleman, 1988 and Sapers 1993).

On the other side, It was found that kaki fruit was very rich in Carotenoids which reached to $49.35 \mathrm{mg} / 100 \mathrm{gm}$. Homnava et al (1990) mentioned that $\beta$ carotene was the predominant carotenoid compounds among 11 of 15 persimmon fruit varieties.

While papaya fruit pulp contained carotenoids about $26.89 \mathrm{mg} / 100 \mathrm{~g}$ on (FWB). These results are in agreement with results obtained by Nasr et al (2001).
Results in Table (2) show that pomegranate had a high value of anthocyanin $140.73 \mathrm{mg} / 100 \mathrm{~g}$ of juice. These results go in line with the results obtained by Hamed (1999).

The tannin content of kaki fruits was $1.37 \%$ while in pomegranate it reached to $0.530 \%$. Tannin is an infavorable component since it negatively affects taste.

The results in Table (3) show that moisture content of different blends were in the same level. Since they ranged from 82.75 to $84.5 \%$.

Total sugars were ranged from $13.26 \%$ (in blend 5) to $16.76 \%$ (in blend 2).

The reducing sugar was always higher than that of non-reducing sugar. The latter constituted about $30.7 \%$ of the total sugars on average.

Total titratable acidity usually affects the taste of the final product. Its highest value was found in blend (1) $0.35 \%$ as citric acid whereas the lowest value was in blend (5) $0.199 \%$. It seems that the acid values were very low when compared with that of total sugars (a phenomenon which could affect the taste) since the ratio of sugar/acid value fluctuated from 44.37:1 in blend No. (1) to 71.39:1 in blend No. (4).

Both ascorbic acid and total carotenoids are considered as potent antioxidant and hence it protects the cells from being damaged by undesirable free radical. In this context, the highest value of ascorbic acid was found in blend No. (2) 45.73 $\mathrm{mg} / 100 \mathrm{~g}$, whereas the lowest value was found in blend No. (3) $35.22 \mathrm{mg} / 100 \mathrm{~g}$. These values could be considered about equal to ascorbic acid content available in the citrus fruits which usually considered as a favorable source of vitamin C. As for carotenoids, the highest value was found 
Table 2. Chemical constituents of different fresh juices extracted from different mature fresh picked fruits

\begin{tabular}{|lcccc|}
\hline \multicolumn{1}{|c}{ Chemical constituents } & Kaki & Papaya & Guava & Pomegranate \\
\hline Moisture content (\%) & 78.70 & 87.32 & 86.23 & 85.87 \\
Total sugars\% & 17.11 & 8.90 & 26.7 & 9.51 \\
Reducing Sugars\% & 16.85 & 3.77 & 12.20 & 6.20 \\
Non-reducing sugars\% & 0.26 & 5.13 & 14.50 & 3.31 \\
Ash \% & 0.63 & 0.57 & 0.54 & 0.38 \\
Crude protein (TN x 6.25) & 0.74 & 0.46 & 0.50 & 0.14 \\
Ascorbic acid mg/100g & 14.79 & 69.50 & 64.58 & 12.4 \\
Carotenoids mg/100g & 49.35 & 26.89 & 7.980 & - \\
Anthocyanin mg/100mg & - & - & - & 140.73 \\
Tannin \% & 1.37 & & & 0.530 \\
Titratable acidity\% & 0.1 & 0.12 & 0.42 & 0.69 \\
$\quad$ (as citric acid) & & & & \\
\hline
\end{tabular}

Table 3. Chemical Constituents of different juice blends

\begin{tabular}{|lccccc|}
\hline \multirow{2}{*}{ Chemical Constituents } & \multicolumn{5}{c|}{ Different blends } \\
\cline { 2 - 6 } & $\mathbf{1}$ & $\mathbf{2}$ & $\mathbf{3}$ & $\mathbf{4}$ & $\mathbf{5}$ \\
\hline Moisture content\% & 84.5 & 84.25 & 83.36 & 82.75 & 84.5 \\
Total sugars\% & 15.53 & 16.76 & 15.86 & 14.85 & 13.26 \\
Reducing sugars\% & 9.75 & 10.46 & 11.17 & 11.4 & 9.03 \\
Non-reducing sugars\% & 5.79 & 6.30 & 4.69 & 3.44 & 4.23 \\
Titratable acidity\% & 0.35 & 0.29 & 0.299 & 0.208 & 0.199 \\
Ascorbic acid mg/100g & 40.32 & 45.73 & 35.22 & 35.94 & 41.18 \\
Carotenoids mg/100g & 20.92 & 25.27 & 26.67 & 33.58 & 26.37 \\
Anthocyanin mg/100g & 35.18 & 14.07 & 28.15 & 14.07 & 28.15 \\
Tannin\% as tannic acid & 0.47 & 0.46 & 0.65 & 0.74 & 0.52 \\
\hline
\end{tabular}


was in blend No. (4) $33.58 \mathrm{mg} / 100 \mathrm{~g}$ whereas the lowest value was found in blend No. (1) $20.92 \mathrm{mg} / 100 \mathrm{~g}$. The carotenoids usually act as a potent antioxidant product which is usually recommended to protect against cancer (Bendich 1991 and Mathews-Roth 1991)

Anthocyanin in acid media has acceptable red color. Its value ranged from $14.07 \mathrm{mg} / 100 \mathrm{gm}$ in blend No. (4) to $35.18 \mathrm{mg} / 100 \mathrm{~g}$ in blend No. (1). The anthocyanin is considered a good natural pigments which usually is used as colorant for food products.

Finally, the tannins are found in large amount in unmature fruits then decrease drastically upon maturation. The final amount of tannin in the prepared blends ranged from $0.46 \%$ in blend No. (2) to $0.74 \%$ in blend No. (4) as tannic acid. These level of tannin however could not affect negatively the organoleptic properties.

Elements in general are of top importance however $\mathrm{Ca}, \mathrm{Zn}, \mathrm{Fe}$ and Se have special nutritional values. Selenium could be considered a good antioxidant and hence it could protect the cells from the attack of free radicals.

Results in Table (4) reveal that pomegranate in general had lower level of different elements. However papaya was the highest $(24 \mathrm{mg} / 100 \mathrm{gm})$ in calcium, but was the lowest in iron $(0.10 \mathrm{mg} / 100 \mathrm{~g})$ meanwhile, the kaki was the highest in iron $(1.76 \mathrm{mg} / 100 \mathrm{~g})$. As for selenium the amounts were almost the same in different fruit juices.

It could be concluded that the variation of different elements could be compensated by blending of different fruit juices.

Table 4. Some selective elements in different fruits

\begin{tabular}{|lcccc|}
\hline \multicolumn{1}{|c}{ Fruits } & $\begin{array}{c}\text { Ca } \\
\mathbf{m g} / \mathbf{1 0 0 g}\end{array}$ & $\begin{array}{c}\mathbf{Z n} \\
\mathbf{m g} / \mathbf{1 0 0 g}\end{array}$ & $\begin{array}{c}\mathbf{F e} \\
\mathbf{m g} / \mathbf{1 0 0 g}\end{array}$ & $\begin{array}{c}\text { Se } \\
\boldsymbol{\mu} / \mathbf{1 0 0 g}\end{array}$ \\
\hline Kaki & 17.6 & 1.52 & 1.76 & 0.53 \\
Papaya & 24.0 & 1.37 & 0.10 & 0.60 \\
Guava & 20.0 & 3.0 & 0.31 & 0.51 \\
Pomegranate & 3 & 0.12 & 0.30 & 0.49 \\
\hline
\end{tabular}

Organoleptic properties are always of high importance since they affect the consumer preference. Results in Table (5) reveal that the higher scores were given to blend No. (2), however the color in general fluctuated between slight pink (No. 2) to deep pink No. $(3,4)$. The scores could be arranged in descending order No. (2) 8.0, No. (1 and 4) 7.9, No. (3) 7.6 and No. (5) 7.15. No significance differences could be observed in color, between different blends.

As for flavor including taste and aroma the differences between scores were almost always insignificant except for blend No. 1 which had the least flavor scores. 
Table 5. Average scores of organoleptic parameters for prepared juice blends

\begin{tabular}{|cllc|}
\hline \multirow{2}{*}{ Blend No. } & \multicolumn{3}{c|}{ Means (x) } \\
\cline { 2 - 4 } & Color & Flavor & Overall Accep. \\
\hline 1 & $7.900 \mathrm{ab}$ & $6.550 \mathrm{~b}$ & $6.750 \mathrm{~b}$ \\
2 & $8.000 \mathrm{a}$ & $7.400 \mathrm{ab}$ & $7.850 \mathrm{~A}$ \\
3 & $7.600 \mathrm{ab}$ & $7.150 \mathrm{ab}$ & $7.650 \mathrm{~A}$ \\
4 & $7.900 \mathrm{a}$ & $7.900 \mathrm{a}$ & $7.850 \mathrm{~A}$ \\
5 & $7.150 \mathrm{~b}$ & $7.050 \mathrm{ab}$ & $7.325 \mathrm{ab}$ \\
\hline L.S.D (0.05) & 0.8026 & 0.8985 & 0.7194 \\
\hline
\end{tabular}

* Values within column followed by the same letter are not significant different $(\mathrm{P}>0.05)$

The overall acceptability scores had the same trend as scores given to flavor. Exclusively, all blends were considered good in the sensory attributes except for blend No. (1). But it could be observed that blends No. (2 and 4) were superior than other blends when compared to flavor and overall acceptability.

\section{REFERENCES}

AOAC (1990). Official Methods of Analysis of the Association of Official Analytical Chemists. $15^{\text {th }}$ Ed. Washington, DC. USA.

Aksu, M.I.; S. Nas and H.Y. Gokalp (1994). Some physical and chemical characteristics of persimmon fruit grown in Artvin-Yusujeli valley. Gida, 19: 367371.

Barbary, O.M. (1991). Effect of storage on sensory and chemical composition of persimmon vinegar. Foods and Biotechnology, 4:75-78.

Bendich, A. (1991). Non-provitamin (A) activity of carotenoids immune enhancement. Trends Food Sci. Tech. 2: 127130.

Chandrika, U.; E.R. Jansz; S.N. Wickramasinghe and N.D. Warnasuriya (2003). Carotenoids in yellow and red fleshes papaya (Carica papaya L.). J. Sci.

Food Agric. 83: 1279-1282.

Chapman, H.D. and P.F. Pratt (1961). Methods of Analysis for Soils, Plants and Water. p. 309, Div. of Agric. Sci. Univ. of California, USA.

Hamed, S.H. (1999). Some Fundamental Aspects Affecting the Processing of Pomegranate Juice. Egyptian. J. of Agricultural Research, 77(3): 1317-1327. Handwerk, R.L. and R.L. Coleman (1988). Approaches to the citrus browning problem. A Review J. Agric. Food Chem. 36(2): 231-236. 
Hirai, S. and K. Yamazaki (1983). Analysis of sugar components of dried Persimmon by gas chromatography. $\boldsymbol{J}$. Jap. Soc. Food. Sci.\& Tech., 30: 178180.

Homnava, A.; J. Payne; P. Koehler and R. Eitenmiller (1990). Pro-vitamin A $(\alpha$ carotene, $\boldsymbol{\beta}$-carotene and $\boldsymbol{\beta}$-cryptoxanthin) and ascorbic acid content of Japanese and American persimmons. J. Food. Quality, 13: 85-95.

Larmond, E. (1970). Method for sensory evaluation of foods. Canada Department of Agriculture, Publication, No. 1284.

Lee, Y.M. and C.C. Kin (1994). Studies on fatty acids composition of sweet persimmon (Diospy kaki L.). J. Korean Soc. for Hort. Sci., 35: 233-240.

Manaba, T. (1993). Quantification of cavity degree in Japanese persimmon for dehydration process. Nippon Shokuhin Kogyo Gakkaishi, 40: 589-595.

Mathews-Roth, M.M. (1991). Recent progress in the medical application of carotenoids. Appl. Chem. 63:147-156.

Nasr, M.A.; A.B. Aisha and M. Siam (2001). papaya fruits (Carica papaya L.) as a promising crop for food processing and cultivation in new arab land in Egypt. Menufiya J. Agric. Res. 26(4): 10971108.

Ott, L. (1984). An Introduction to Statistical Methods and Data Analysis. $2^{\text {nd }}$ Edition, pp. 6-8. PWS Publishers, Boston, Ma, USA.

Pal, D.K.; M.D. Subramanyam; M.G. Divakar; C.P. Lyer and Y. Selvaraj (1980). Studies on physo-chemical com- position of fruits of twelve papaya varieties. J. Food Sci. and Tech., India 17(6): 254-256.

Philip, T. and T.S. Chen (1988). Quantitative analysis of major carotenoid fatty acids esters in fruit by liquid chromatography, persimmon and papaya. J. Food Sci., 53: 1720-1722.

Ranganna, S. (1979). Manual of Analysis of Fruit and Vegetable Products. p. 534. Tata Mc Graw - Hill Publishing. Co., Ltd., New Delhi.

Sapers, G.M. (1993). Browning of foods: control by sulfites, antioxidants and other means. J. Food Technol.: 57(10): 75-92.

Scudamore, S.P.D. (1987). Processing evaluation of seedling and clonal guavas. Food Technology in Australia 39(3): 9295.

Shrede, G.; R.E. Worlstad; P. Lee and G. Enersen (1992). Color stability of strawberry and black current syrups. $\boldsymbol{J}$. Food Sci., 57(1): 172.

Subramanyam, M.D.; D.K. Pal; C.P. Divakor and Y. Selvarai (1986). Studies on the physiochemical composition of fruits of twelve papaya varieties. Indian Food Baker, November, pp. 26-28.

Tressler, D.K. and M.A. Joslyn (1971). Fruit and Vegetable Juice Processing Technology. $2^{\text {nd }}$ Ed. pp. 13-23, AVI Publishing Co., Westport, Connecticut, USA.

Tsuji, M. and Y. Komiyama (1987). Relationship between invertase activity and sugar composition of persimmon fruit. J. Jap. Soc. Food. Sci \& Tech. 43: 425-431. 


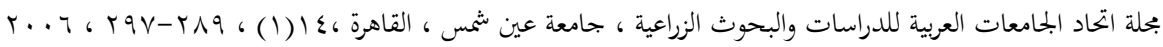

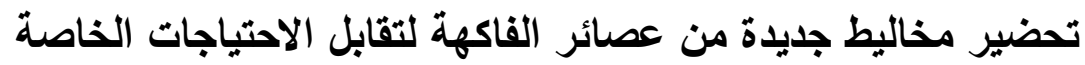

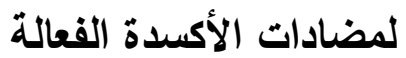

[19]

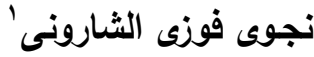

1 - معهد بحوث تكنولوجيا الأغذية - مركز البحوث الزراعية - الجيزة - مصر

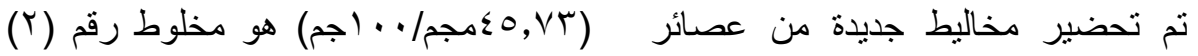

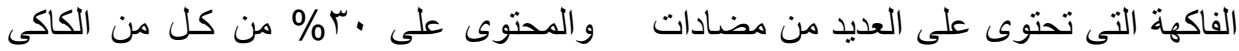

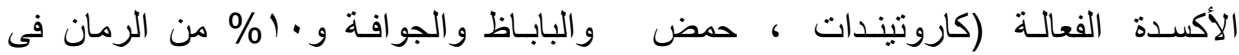

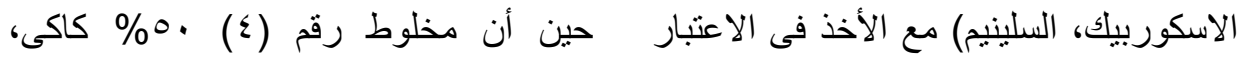

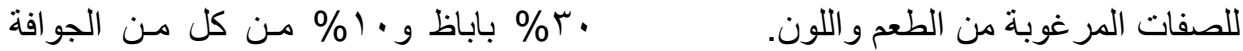

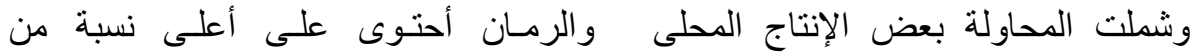

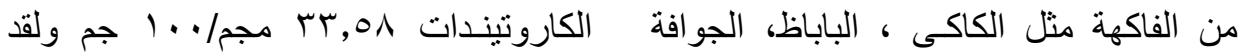

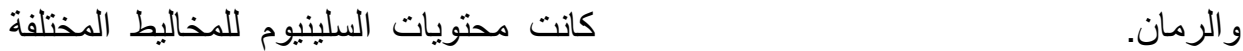
ولقد حضرت م مخاليط بنسب مختلفة تقريبًا ودائمًا متساوية.

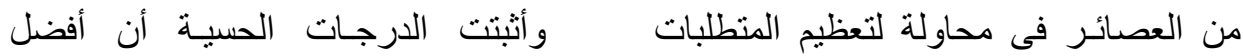

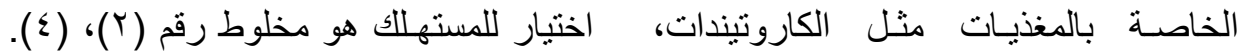

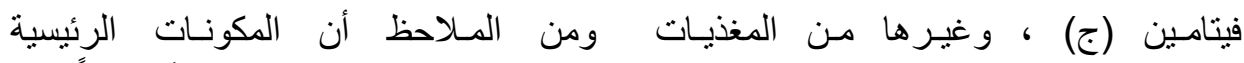

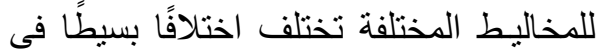

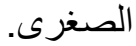
وكانت أفضل المخاليط التى احتوت على محتو اها من السكر و الحموضة الكلية.

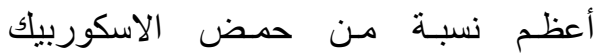

$$
\text { تحكيم: أ.د نجوى موسى حسن رسمي }
$$

